\title{
XXXI. On haydenite and couzeranite
}

\section{H.J. Brooke Esq. F.R.S.}

To cite this article: H.J. Brooke Esq. F.R.S. (1840) XXXI. On haydenite and couzeranite, Philosophical Magazine Series 3, 16:102, 175-175, DOI: 10.1080/14786444008650014

To link to this article: http://dx.doi.org/10.1080/14786444008650014

册 Published online: 01 Jun 2009.

Submit your article to this journal 준

Џ Article views: 2

Q View related articles $₫$ 
able to show, in each case, that my original views have been supported by a careful re-examination of the facts.

Dublin, January $17,1840$.

XXXI. On Haydenite and Couzeranite. By H. J. Вrooke, Esq., F.R.S.*

T $N$ the last Number of the Phil. Mag. p. 156, I observed a notice of a new nineral (Beaumontite) which $M$. Levy has found accompanying Haydenite, a mineral that is said to occur near Baltimore in the United States; and M. Levy remarks that I have classed Haydenite with Heulandite without assigning any reason for so doing.

I did so from perceiving that the small and brilliant yellowish crystals on the specimen I examined resembled Heulandite, in having a nacreous plane in only one direction, corresponding with the $\mathrm{P}$ of W. Phillips (Mineralegy, p. 39 . Ed. 1823); in the form, as far as I could distinguish it in the minute and closely aggregated condition of the crystals; and in the near agreement, about $112^{\circ}$, of the angle between the nacreous plane and a plane appearing to correspond with the $a$ of W. Phillips.

M. Levy is doubtless aware of a variety of Heulandite found at Arendal, of a brown or yellowish brown colour, in small bright crystals, and accompanied by stilbite in globularly-radiated concretions of a dull yellowish colour. 'The specimen sent to me from America as Haydenite has a similar accompaniment of stilbite of the same description, and this circumstance tended to confirm my impression that Haydenite was Heulandite. It is probable, therefore, that the specimen sent to me from America as Haydenite, is really not that mineral, and I do not find anything like M. Levy's Beaumontite upon it, except that the crystals are "small and brilliant, and of a pearly lustre." Mr. L. does not say on what faces this lustre appears in Beaumontite.

I find I have been formerly led into an error relative to Couzeranite by specimens received from Paris, by $\mathrm{Mr}$. Heuland, from $\mathrm{Mr}$. Pentland. On examining the crystals I found them to be felspar, and I accordingly stated, on the faith of the specimens so transmitted to Mr. Heuland being genuine, that Couzeranite was only felspar. I have since seen other specimens named Couzeranite in apparently square prisms, and if these are the true mineral it has no resemblance whatever to felspar.

H. J. B.

* Communicated by the Author. 